\title{
Detection by ELISA of Predators of Prays oleae (Lepidoptera: Plutellidae) in a Portuguese Olive Orchard
}

\author{
C. Lozano, T. Morris and M. Campos \\ J.A. Pereira and A. Bento \\ Estación Experimental del Zaidín (CSIC) Escola Superior Agrária de Bragança \\ Profesor Albareda 1, 18008 Granada, Spain Apdo 172, 5300 Bragança, Portugal
}

Keywords: P. oleae, predators, ELISA, olive

\begin{abstract}
Over 900 predators were collected during two years from a Portuguese organic olive orchard, and tested in a serological bioassay for Prays oleae predation. The highest number of predators tested positive during the phyllophagous and antophagous generations of $P$. oleae. Ants were the most commonly found predators, followed by Coleoptera, Hemiptera and spiders.
\end{abstract}

\section{INTRODUCTION}

Olive is an important crop in Portugal, grown over a surface of 360000 ha. Among its pests, Prays oleae (Lepidoptera: Plutellidae), is the most important. This moth has three generations a year, phyllophagous, antophagous and carpophagous, the last one, which presents infestation levels of up to $60 \%$ being responsible for the highest damage (Bento, 1999). Control methods are chemical applications and the use of Bacillus thuringiensis. Concerning the auxiliary fauna the most important agents of biological control are parasitoids, with predators having a minor role.

A recent study of $P$. oleae predators in southern Spanish olive orchards was carried out using immunological techniques such as ELISA (Morris et al., 1999). This test is based on the identification of the remains of specific preys (antigen) in the stomach of predators using prey-specific antibodies (Hagler and Naranjo, 1994; Symondson et al., 1996). According this study, the main P. oleae predators detected were ants, followed by Heteroptera and Coleoptera. The aim of the present work is the detection by ELISA of predators of $P$. oleae in a Portuguese olive orchard.

\section{MATERIAL AND METHODS}

The investigation was carried out in an organic olive orchard from the North of Portugal in Paradela (Mirandela) (UTM 29 PG5602). Sampling was from April to July 1998 and from March to June 1999, because during these months $P$. oleae is more vulnerable to predators, which occur in large numbers (Morris et al., 1999). The presence of the different developmental stages of $P$. oleae was followed through weekly observations of 25 inflorescences and 25 fruits per tree of 25 trees in total, and by recording the presence of adults with five pheromone traps.

Collection of predators was done in a total of 50 trees, which were sampled weekly. In each tree a branch (c. $1 \mathrm{~m}$ long) was shaken five times, and the material was collected in a entomological net. A crude extract was obtained from each predator.

The immunoassay used for detection of predation was indirect ELISA using Morris (1997) antiserum. Each plate was calibrated with a dilution series obtained from a solution 1: $20000(\mathrm{p} / \mathrm{v})$ of $P$. oleae (antigen), with which the relation between absorbance and concentration levels was established. The threshold used to discriminate positive reactions, was the average plus 2,5 times the standard deviation of the equivalent concentration of the species Calliphora vomitoria which produced the highest cross reaction, among the 25 arthropods species present in the surveyed area.

\section{RESULTS AND DISCUSSION}

$P$. oleae adults captured per trap during 1998 were 527 (SD: 132.7) of the phyllophagous generation and 987 (SD: 107.4) of the anthophagous generation. In 1999,

Proc. $4^{\text {th }}$ IS on Olive Growing 
the number of adults captured during the above mentioned generations was 584 (SD: 17.4) and 1969 (SD: 148.2), respectively.

In the first year, the predators that gave a positive answer were found in the second half of June and the first week of July (Table 1), coinciding with the presence of eggs and the just emerged larvae of the carpophagous generation. The absence of positives during the anthophagous generation in 1998, may be due to the relatively low population of $P$. oleae and the scarce number of predators captured during April and May of that year. In the second year positives were mainly obtained both at the end of March and first fortnight of April, which led to the conclusion that predators were active primarily on fifth age larvae and pupae of the phyllophagous generation, and at the end of April - first half of May, when the developmental stages of the antophagous generation were present. According to Morris et al. (1999), larvae of the flower generation are more susceptible to be predated, which tallies with the results obtained during the second year.

Ants were the most frequent predator group (Fig. 1), which constitute also, if we consider all the years, the largest group that gave positive ELISA reactions (Table 2). This may be due to the type of agronomic practices applied in the olive orchard, which favours the presence of ants (Redolfi et al., 1999). Other groups that showed a relation with the phytophagous generation are Coleoptera, spiders and hemiptera (Fig. 1), whose captures and occurrence over $P$. oleae vary according to the year (Table 2). Chrysopids were the minor group, which contrasts with the observations of Bento (1994) in Portuguese olive orchards, who indicated Chrysoperla carnea as one of the most frequent species among the natural enemies of $P$. oleae. In other olive orchards, chrysopids are also considered as the main predator group of this moth (Alrouechdi et al., 1981, Campos and Ramos, 1985; Sacchetti , 1990). Morris (1997) explains the low captures obtained with differences in the method of sampling. Our results improve the knowledge of the distinct components and interactions which exist in olive grove agrosystems, and may help defining potential candidates for the biological control of $P$. oleae.

\section{ACKNOWLEDGEMENTS} ICCTI.

The present work was supported in part by the program Comisión Mixta CSIC-

\section{Literature Cited}

Alrouechdi, K., Pralavorio, R., Canard, M. and Arambourg, Y. 1981. Coincidence et relations prédatrices entre Chysoperla carnea (Stephens) (Neur., Chrysopidae) et quelques ravageurs de l'olivier dans le sud-est de la France. Zeitschrift für Angewandte Entomologie, 91: 411-417.

Bento, A. 1994. Estudo sobre a traça da oliveira, Prays oleae (Bern.) na Terra Quente Transmontana na óptica da protecçao integrada. Disset. Curso Mest. Em Prot. Int. UTL/ISA, Lisboa, 209 pp.

Bento, A. 1999. Contribuiçao para o estabelecimento de um programa de protecçao integrada contra a traça da oliveira, Prays oleae (Bern.) em Trás-os-Montes. Tese de Doutoramento, UTAD, Vila Real, 277 pp.

Campos, M. and Ramos, P. 1985. Some relationship between the number of Prays oleae eggs laid on olive fruits and their predation by Chrysoperla carnea. In: Cavalloro, R., Crovetti, A. (Eds.). Integrated Pest Control in Olives Groves. Pisa: 237-241.

Hagler, J.R. and Naranjo S.E. 1994. Determining the frecuency of heteropteran on sweetpotato whitefly and pink bollworm using multiple ELISAs. Entomologia Experimentalis et Applicata. 72: 59-67.

Morris, T.I. 1997. Interrelaciones entre olivos, plagas y depredadores. Ph. D. Thesis, University of Granada.

Morris, T.I., Campos, M., Kidd, N.A.C. and Symondson, W.O.C., 1999. What is consuming Prays oleae (Bernard) (Lep.: Yponomeutidae) and when: a serological solution?. Crop Protection 18: 17-22.

Redolfi, I., Tinaut, A., Pascual, F. and Campos, M., 1999. Qualitative aspects of 
myrmecocenosis (Hym: Formicidae) in olive orchards with different agricultural management in Spain. Journal of Applied Entomology, 123: 1-7.

Sacchetti, P., 1990. Osservazioni sull'attività e sulla bioetologia degli entomifagi di Prays oleae (Bern.) in ToscanaI. I predatori. Redia 73: 243-259.

Symondson, W.O.C., Glen, D.M., Wiltshire, C.W. Langdon, C.J. and Liddell, J.E., 1996. Effects of cultivation techniques and methods of straw disposal on predation by Pterostichus melanarius (Coleoptera: Carabidae) upon slugs (Gastropoda: Pulmonata) in an arable filed. Journal of Applied Ecology, 33: 741-753

\section{Tables}

Table 1. Number of individuals tested in ELISA and percentage of positives for $P$. oleae consumption

\begin{tabular}{|c|c|c|c|c|c|}
\hline \multirow[b]{2}{*}{ DATE } & \multicolumn{2}{|l|}{1998} & \multirow[b]{2}{*}{ DATE } & \multicolumn{2}{|c|}{1999} \\
\hline & INDIVIDUALS & $\begin{array}{c}\text { POSITIVES } \\
(\%)\end{array}$ & & INDIVIDUALS & $\begin{array}{c}\text { POSITIVES } \\
(\%)\end{array}$ \\
\hline 30 April & 8 & 0 & 29 March & 31 & 19,3 \\
\hline 06 May & 11 & 0 & 06 April & 36 & 8,1 \\
\hline 14 May & 3 & 0 & 12 April & 63 & 1,5 \\
\hline 21 May & 8 & 0 & 19 April & 62 & 0 \\
\hline 28 May & 15 & 0 & 26 April & 39 & 2,6 \\
\hline 04 June & 11 & 0 & 04 May & 53 & 16,7 \\
\hline 11 June & 6 & 0 & 10 May & 50 & 1,9 \\
\hline 18 June & 22 & 4,5 & 17 May & 48 & 0 \\
\hline 25 June & 16 & 6,2 & 24 May & 61 & 1,5 \\
\hline 02 July & 58 & 13,8 & 31 May & 36 & 0 \\
\hline 09 July & 28 & 0 & 07 June & 47 & 0 \\
\hline & & & 14 June & 48 & 4,1 \\
\hline & & & 21 June & 35 & 0 \\
\hline TOTAL & 211 & 5,2 & & 611 & 3,9 \\
\hline
\end{tabular}

Table 2. Percentage of predators ELISA-positive for Prays oleae consumption (and total number assayed) in their respective taxonomic groups

\begin{tabular}{llcc} 
Group & 1998 & 1999 & Total \\
\hline Spiders & $0(28)$ & $4.1(146)$ & $3.4(174)$ \\
Coleoptera & $6.5(31)$ & $3.9(177)$ & $4.3(208)$ \\
Chrysopidae & $0(5)$ & $0(10)$ & $0(15)$ \\
Hemiptera & $6.1(65)$ & $0(93)$ & $2.5(158)$ \\
Ants & $6.1(82)$ & $5.5(183)$ & $5.6(265)$ \\
\hline
\end{tabular}


$\underline{\text { Figures }}$

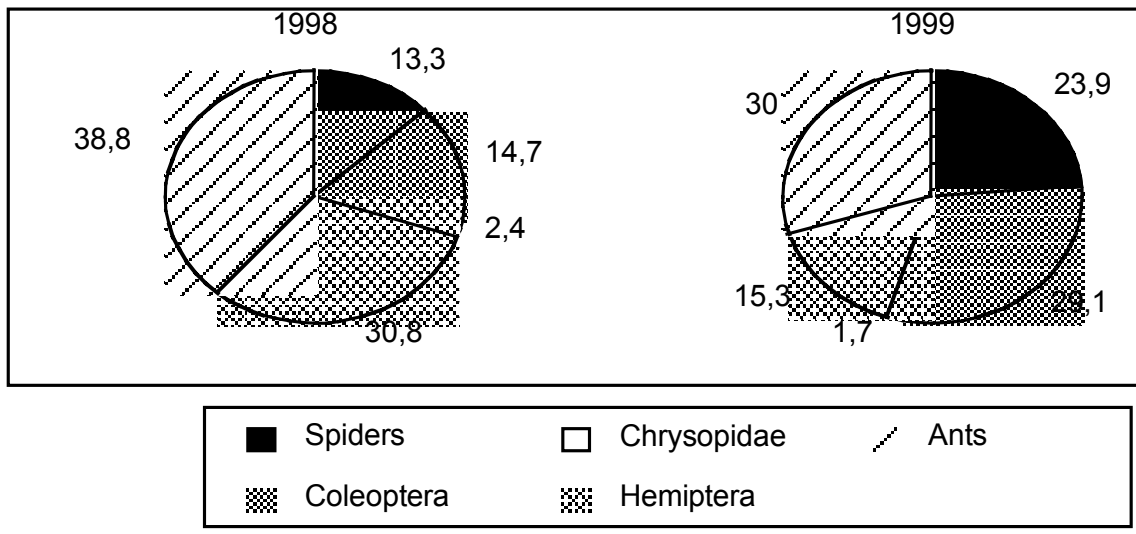

Fig. 1. Percentage of different predators collected in 1998 and 1999. 